\title{
A Rich Concept of Wealth Creation Beyond Profit Maximization and Adding Value
}

\begin{abstract}
The purpose of this article is to take a fresh look at the concept of wealth creation that is urgently needed, given the huge gap between the global importance of wealth creation and the attention paid to it. It is argued that its notion we encounter is often very simple (as in "making money") or extremely vague (as in "adding value"). In the first section "Need for a fresh look at the creation of wealth", the need for a fresh look is highlighted by pointing to three concerns about globalization and the roles and responsibilities of corporations. In the second section "Conceptual clarifications: what is the creation of wealth?", a rich concept of wealth creation is developed that includes physical, financial, human, and social capital, encompasses private and public wealth, accounts for its production and distribution, recognizes its material and spiritual side, and places wealth in the time horizon of sustainability. Moreover, creating (wealth) as "making something new and better" is distinguished from possessing and acquiring, and different motivations required for wealth creation are explored. The third section "Challenges for business ethics" discusses several challenges of this rich concept for the understanding of business ethics.
\end{abstract}

KEY WORDS: corporate social responsibility, different concepts of capital, globalization, poverty, private and public wealth, profit maximization, purpose of corporations, sustainability, wealth creation

"Making money" can be destroying wealth while creating wealth can be losing money.

A thorough understanding of wealth creation enables us to sharpen our economic critique of fashionable and short-sighted management recipes and to bring the power of ethics to bear where it matters most.

\section{Need for a fresh look at the creation of wealth}

The purpose of this article is to take a fresh look at the concept of the creation of wealth. We need a fresh look because the notion of wealth creation we encounter is often very simple (as in "making money") or extremely vague (as in "adding value"). Moreover, the urgency for a fresh look becomes even more articulated and pressing when we envision the global importance of wealth creation and its widespread factual neglect. Not only need we better understand what wealth creation really is, but we also need to understand how it should be valued in the global context from moral, cultural, and religious perspectives. Therefore, the search for the meaning of wealth creation can't be conducted but in both a critical and a constructive approach. ${ }^{1,2}$

In order to illustrate the huge gap between the global importance of wealth creation and the attention paid to it, I would like to point to three concerns about globalization, and the roles and responsibilities of corporations.

\section{Winners and losers in the process of wealth creation} over the last 50 years

The first concern is highlighted in the fascinating and powerful historic account "why some [nations] are so rich and some so poor," of Landes (1999), who scrutinizes the winners and losers in the process of wealth creation over the last 50 years. On the winners' side, in addition to "the 30 wonderful years from 1945 to 1975" of France and the "economic 
miracle" in Germany, he highlights the East Asian success stories of Japan, the four "Little Tigers" (South Korea, Taiwan, Singapore, and Hong Kong), and the regional followers such as Malaysia, Thailand, and Indonesia, referring, among others, to the World Bank's study The East Asian Miracle (1993), and adding China in his "Epilogue 1999" (Landes, 1999, pp. 524-531). The losers are the Middle East, Latin America, the countries of the Communist-Socialist bloc, and sub-Saharan Africa.

We may add some historic trends based on the World Bank's "World Development Indicators." The first set of charts (Figures 1, 2, 3, 4; World Bank, 2007) depicts the annual growth rates in percent of the Gross Domestic Product (GDP) in different world regions (showing only the values of every third year and with varying scales of the vertical axis). It also contains the GDP growth rates in percent per capita, accounting for the changes of the respective populations over the years. Of course, these indicators can provide only a very rough picture of what might be called "creation of wealth."

Among others, it does not account for environmental degradation. Therefore, we supplement the growth rates with $\mathrm{CO}_{2}$ emissions (metric tons per capita) as an indicator of this kind of degradation. It turns out that the "winners" over the last 15 years are East Asia and the Pacific, as well as South Asia. Little economic growth with some negative annual growth rates can be found, in decreasing order, in the Middle East and North Africa, Latin America and the Caribbean, Europe and Central Asia, and Sub-Saharan Africa. Overall, High Income countries $(\$ 10,066$ and above in 2004) showed low annual growth rates of GDP and GDP per capita (an average of $2.4 \%$ and $1.7 \%$, respectively), but very high levels of $\mathrm{CO}_{2}$ emissions (12 and more metric tons per capita). In contrast, Low Income countries ( $\$ 823$ or less in 2004$)$ had higher growth rates (i.e., $5 \%$ and $3 \%$, respectively) and very low levels of $\mathrm{CO}_{2}$ emissions ( 1 metric ton per capita).

The second set of charts (Figures 5, 6, 7; World Bank, 2007) shows the ratio of the poverty population as an important aspect of the unequal distribution of wealth, namely, the poverty headcount ratio at $\$ 1$ and $\$ 2$ a day (in purchasing power parity) as percentage of the entire population in 1990 and 2002 (which are the only available data for that period of time). While the
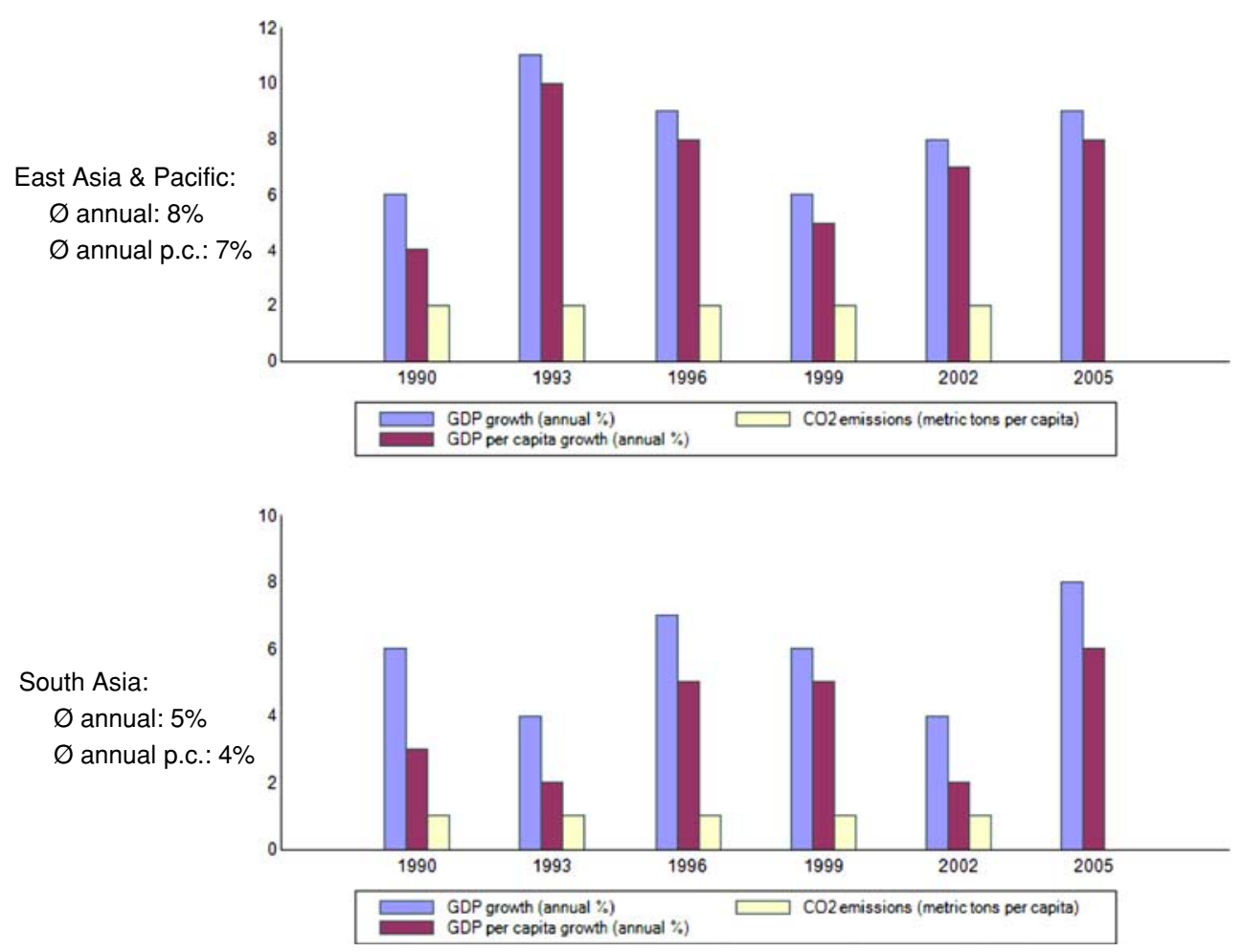

Figure 1. Strong economic growth: GDP growth, GDP per capita growth, $\mathrm{CO}_{2}$ emissions. 

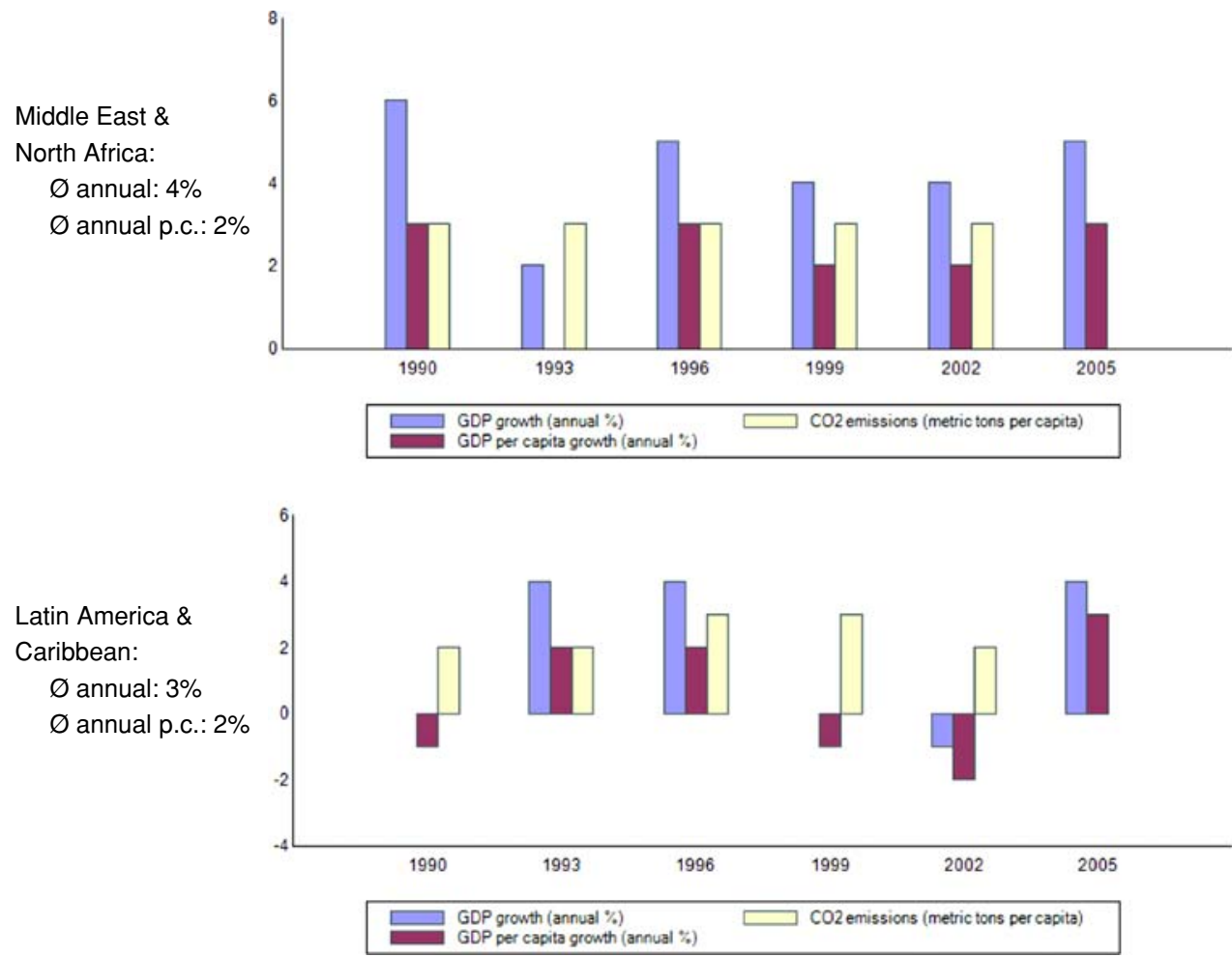

Figure 2. Little economic growth: GDP growth, GDP per capita growth, $\mathrm{CO}_{2}$ emissions.
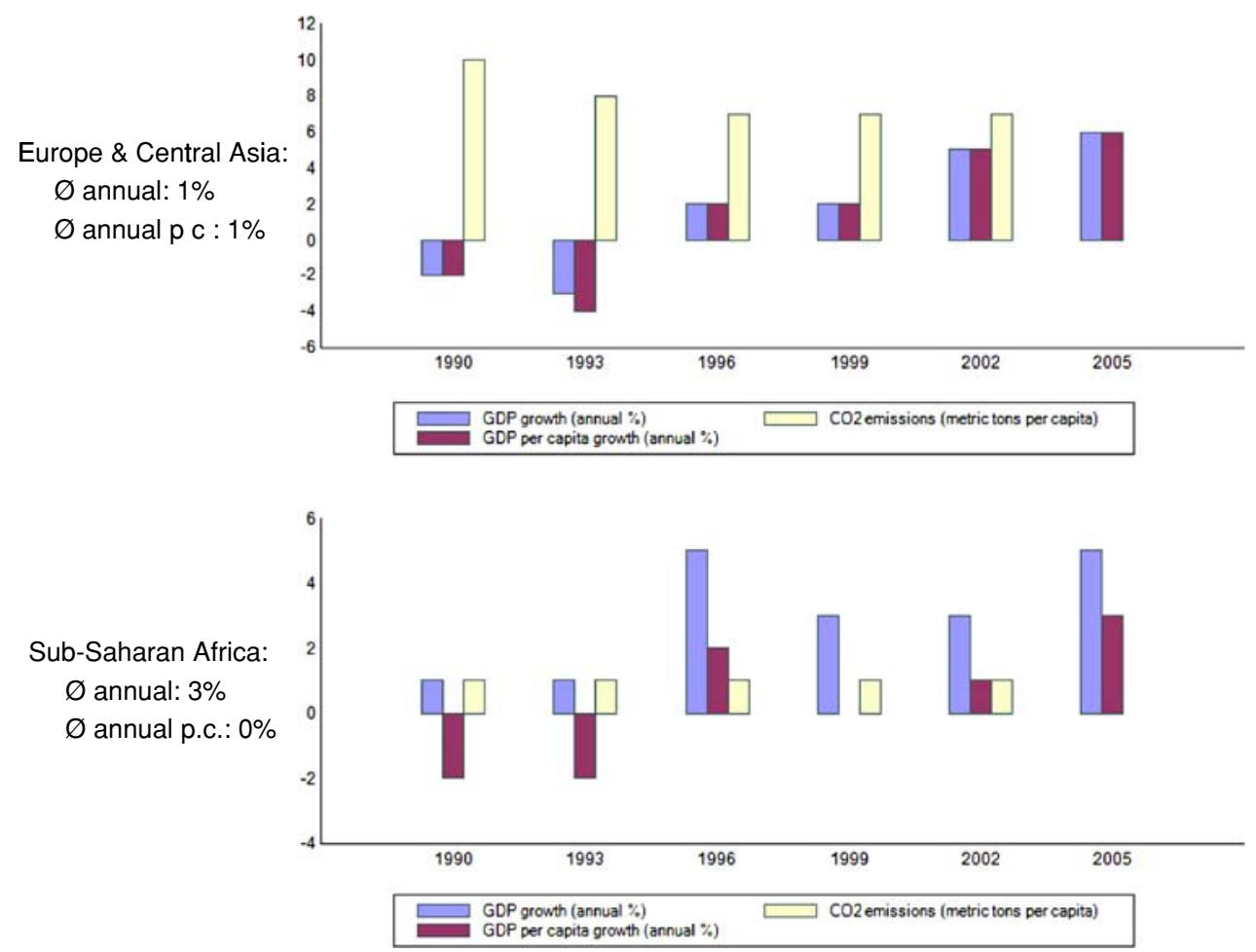

Figure 3. Little economic growth: GDP growth, GDP per capita growth, $\mathrm{CO}_{2}$ emissions. 

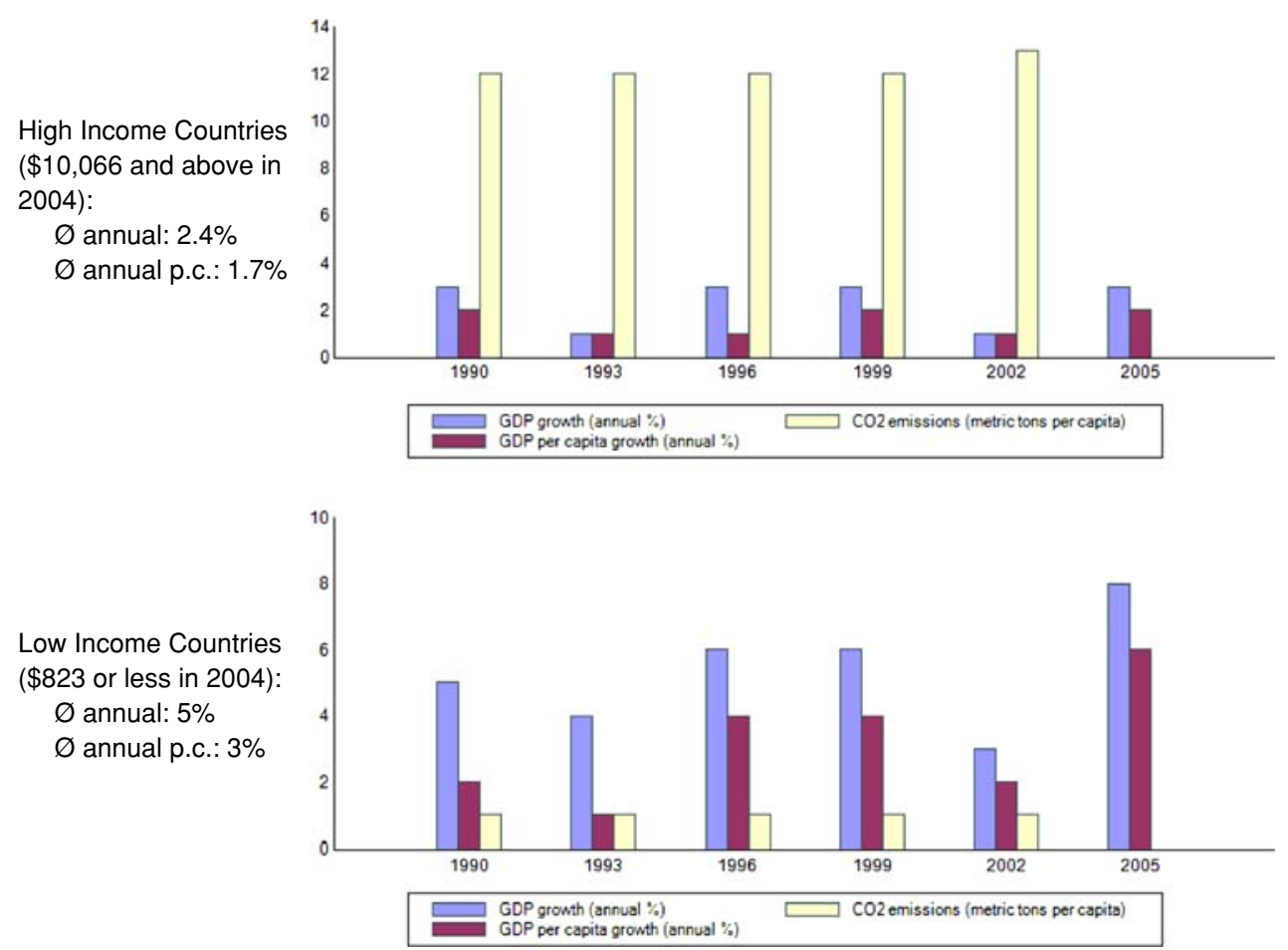

Figure 4. GDP growth, GDP per capita growth, $\mathrm{CO}_{2}$ emissions.

poverty ratios decreased dramatically in East Asia and the Pacific and considerably in South Asia, they declined only slightly in Latin America and the Caribbean, and in the Middle East and North Africa, stagnated in Sub-Saharan Africa, and even increased markedly in Europe and Central Asia.

Obviously, these very diverse developments have been caused by multiple factors which cannot be discussed at present. However, these factors are enormous and provide paramount import to the question of how we may understand the creation of wealth with its environmental and distributional implications.

\section{Wealth creation: a blind spot of CSR?}

A second concern relates to the worldwide discussions about "corporate social responsibility," or CSR, which have gained considerable momentum in the last 10 years. Corporations are expected to care about their environmental impact, to behave as corporate citizens, to defend freedom on the internet, to support cultural and sports events in their communities, to help the victims of natural disasters such as the tsunami and Katrina, to provide health care at reduced prices or for free to the needy who cannot afford it, etc. Against the backdrop of this wealth of expectations, it is striking that, quite often, the financial and economic responsibilities of business organizations seem to be ignored, and, more specifically, no attention is paid to the questions of how companies can and should create wealth. In fact, creating wealth seems to have nothing to do with the social responsibility of companies.

What is the economic underpinning of "maximizing shareholder value" and "adding value"?

Finally, on surveying the management literature, a third concern arises. It seems fair to say that a large proportion of this literature assumes the companies' objective of "maximizing shareholder value," giving it no critical examination in economic terms. A prime example is found in the survey "The Good Company" published by The Economist in January 2005. The authors present and criticize the almost irresistible rise of the CSR movement and conclude by falling back on Milton Friedman's catchy but poorly 
East Asia \& Pacific: at $\$ 1$ : reduction of $18 \%$ at \$2: reduction of $29 \%$

South Asia:

at $\$ 1$ : reduction of $10 \%$ at $\$ 2$ : reduction of $8 \%$
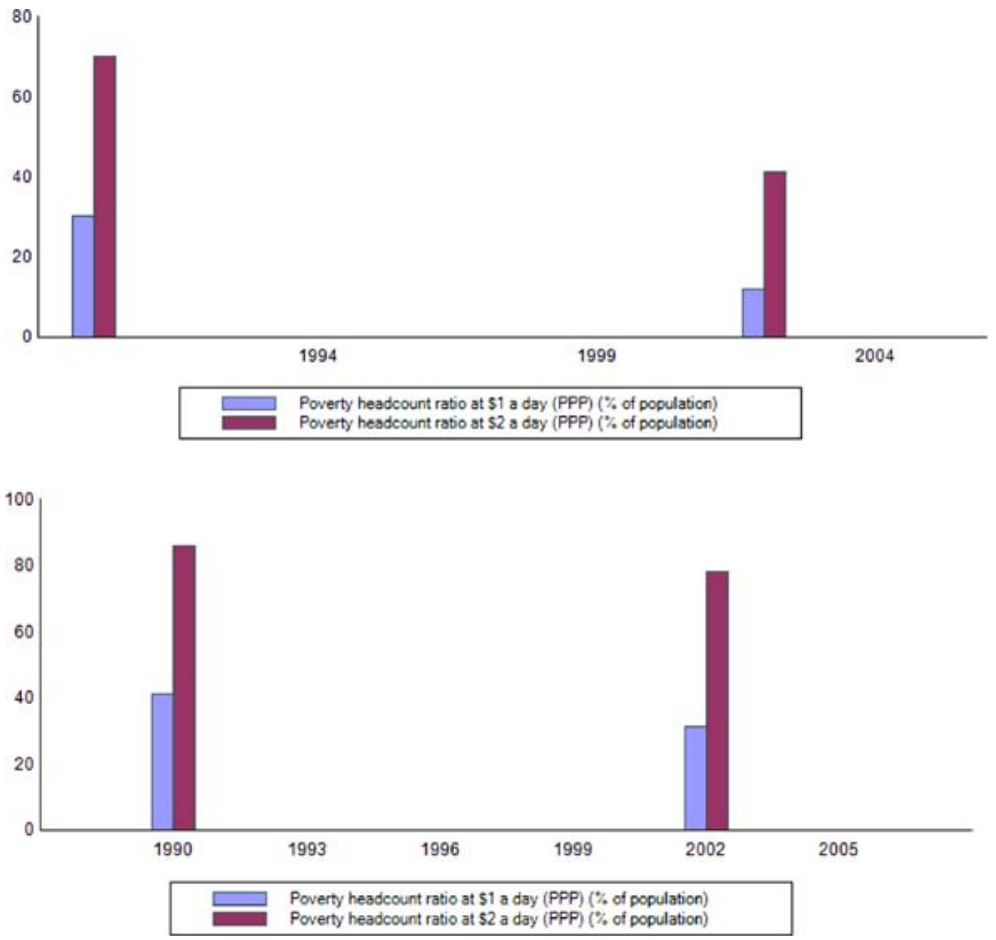

Figure 5. Significant poverty reduction: poverty headcount at $\$ 1$ and $\$ 2$ a day (PPP) (\% in population in 1990 and 2002).
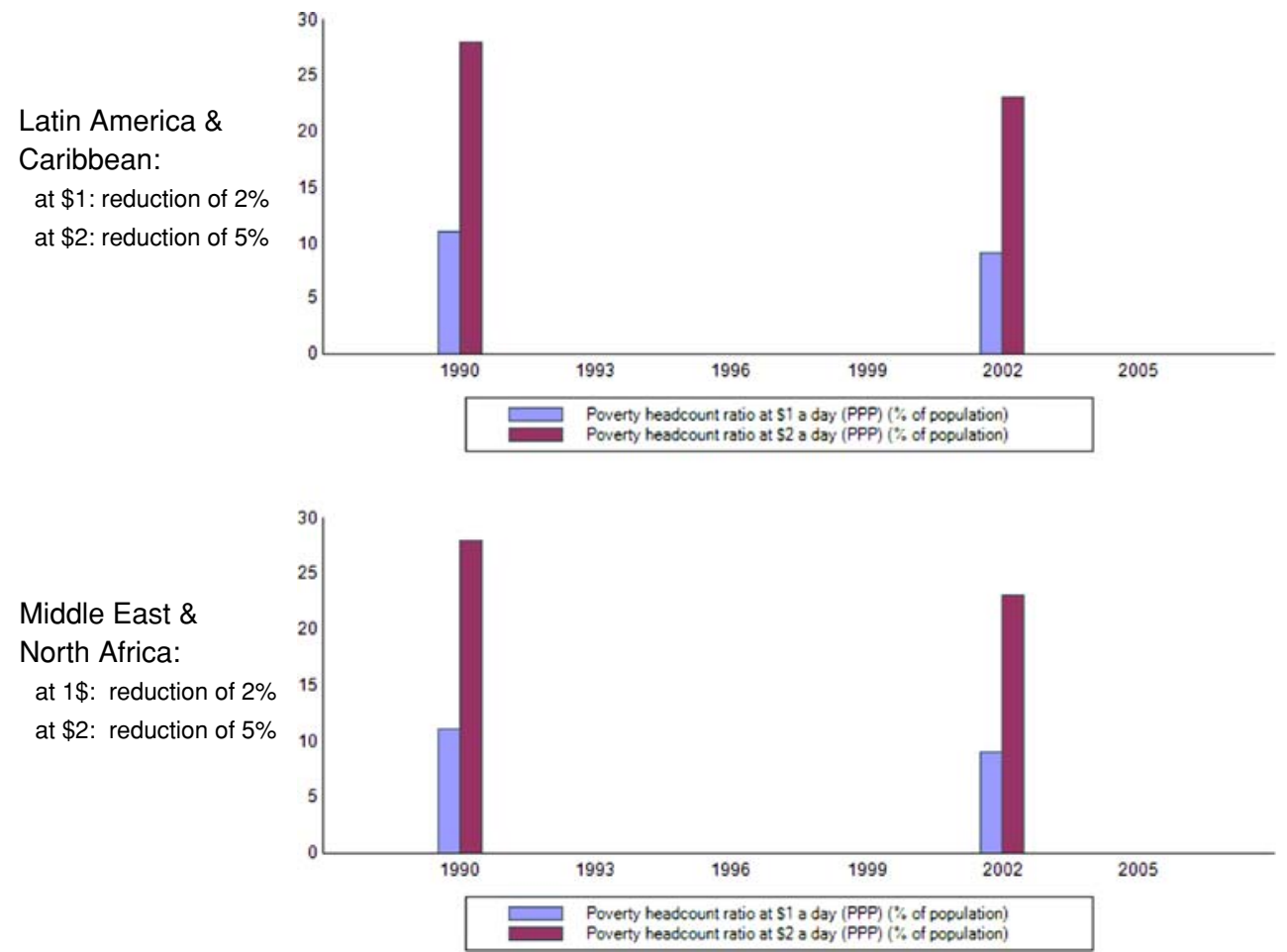

Figure 6. Modest or no poverty reduction: poverty headcount at $\$ 1$ and $\$ 2$ a day (PPP) (\% in population). 

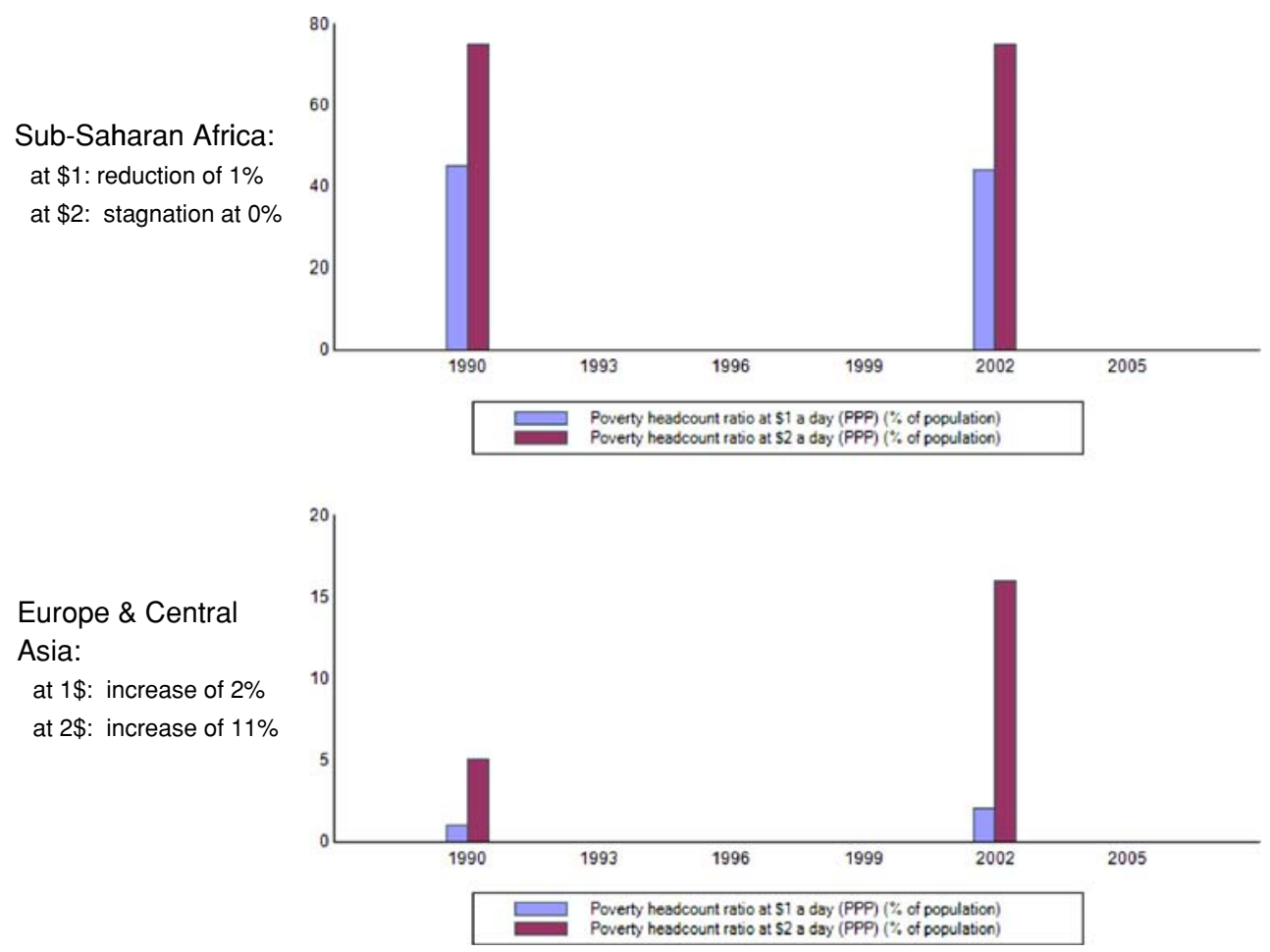

Figure 7. Stagnation or poverty increase: Poverty headcount at $\$ 1$ and $\$ 2$ a day (PPP) (\% in population).

grounded slogan of 1970 "The business of business is business. Period." Moreover, when the broader objective of "adding value" is adopted, it is unfortunately often used as a black box that can be filled with any type of the so-called "value." Indeed, the notion of wealth creation is not seriously scrutinized even by prominent writers like Collins and Porras (Collins, 2001; Collins and Porras, 1994). Here again, in the management literature, we can often observe a strange phenomenon that the notion of wealth creation is taken for granted without critical reflection.

\section{Conceptual clarifications: what is the creation of wealth?}

Wealth can be defined in several ways. As Heilbroner states (1987, p. 880), "wealth is a fundamental concept in economics indeed, perhaps the conceptual starting point for the discipline. Despite its centrality, however, the concept of wealth has never been a matter of general consensus." As for the term itself, it figures prominently in Adam Smith's book, An Inquiry Into the Nature and Causes of the Wealth of
Nations (1776), but is conspicuously absent from Gunnar Myrdal's book, Asian Drama: An Inquiry Into the Poverty of Nations (1968) and is complemented with its opposite in David Landes's book, The Wealth and Poverty of Nations: Why Some Are So Rich and Some So Poor (1999). It is noteworthy to see how Smith's "wealth" is translated into other languages: as Wohlstand prosperity (not as: Reichtum riches, Wohlfahrt welfare, Vermögen wealth) in German, richesse riches in French, riqueza riches in Spanish, and fù rich in Chinese. Figure 8 offers an overview of the components of wealth creation as they are presented in the following.

In order to discuss the concept of wealth, we first might concentrate on what is meant by the wealth of a single nation. While this approach may seem outmoded and inappropriate because of the "decline of the nation-state" in present times, the increasing number of pressing international challenges and the extraordinary power of many transnational corporations; however, it provides some advantages when compared to other approaches. When we ask for the "wealth of a nation," it is difficult to deny that wealth should encompass both private and public goods or 


\begin{tabular}{|c|c|c|}
\hline & WEALTH & \\
\hline $\begin{array}{l}\text { CREATING } \\
\neq \text { possessing } \\
\neq \text { acquiring } \\
\text { but: } \\
\text { making something } \\
\text { new and better }\end{array}$ & physical, financial, human, social capital & $\begin{array}{l}\text { MOTIVATIONS } \\
\text { for creating wealth } \\
\text { self- and other- } \\
\text { regarding: } \\
\text { self-interest } \\
\text { joy of finding } \\
\text { entrepreneurial spirit } \\
\text { service to others }\end{array}$ \\
\hline \multicolumn{3}{|c|}{$\begin{array}{l}\text { Examples of countries: } \\
\text { "The thirty wonderful years from } 1945 \text { to 1975" of France } \\
\text { "The economic miracle" of Germany (after 1945) } \\
\text { "The East Asian Miracle" (1960-1990) in Japan, South Korea, Singapore, Hong Kong, } \\
\text { Malaysia, Thailand, and Indonesia } \\
\text { China (since 1980) }\end{array}$} \\
\hline
\end{tabular}

Figure 8. A rich concept of wealth creation.

assets, that is, endowments of two types: those that can be attributed to and controlled by individual actors, be they persons, groups, or organizations, and those from which no actor inside the nation can be excluded. (In technical economic terms, "public goods" are defined by the characteristics of non-rivalry and non-exclusive consumption; see Enderle, 2000). For instance, a SARS-free environment is a "public good" and a SARS-threatened environment a "public bad" that has clearly a material component, even though it might be difficult to put a price on it.
It is obvious that the functioning of the markets and the production of private goods depend on such public goods and public bads. In contrast, when speaking of the wealth of an individual or a company, we usually consider only the assets under its control, while ignoring the public goods it also benefits (or suffers) from. In the international realm, public goods are only beginning to be discussed, although they are of increasing importance and often the driving force for transnational regimes and institutions (see, e.g., Kaul et al., 1999). 
We may define the wealth of a nation as the total amount of economically relevant private and public assets including physical (or natural), financial, human, and "social" capital. Consequently, the creation of wealth includes the production of public as well as private assets, which indicates the important but limited role of the market and price mechanism. Wealth is primarily a stock (an economically relevant quantity at a certain point in time); but, in a broader sense, it also includes flows (increasing or decreasing quantities over a certain period of time). This basic distinction in economics is particularly relevant for our discussion on wealth because flows such as income per person, a commonly used indicator of the development of a country, express the economic situation of an economic actor only inadequately; the expected flows in the future are subject to a great deal of uncertainty and risk.

Another fundamental issue, fraught with multiple difficulties, is the question of how wealth as "economically relevant stocks and flows" can be properly expressed in monetary terms and added up to a total amount of money. From the recent experiences of the U.S. Stock Market, we all know that there might be huge gaps between the real economic and the monetary performances of companies, as the monetary indicators are only reliable if the markets function properly. Even then, this pertains only to private and not to public goods. In other words, sound economic thinking offers serious caveats against equating money with wealth. "Making money" can be destroying wealth while creating wealth can be losing money. It goes without saying that making money and creating wealth should go hand in hand.

What do we mean by the "creation" of wealth? Obviously, wealth creation is both more than possessing wealth and is only one form of increasing wealth. According to Jacob Viner, "Aristotle ... insisted that wealth was essential for nobility, but it must be inherited wealth. Wealth was also an essential need of the state, but it should be obtained by piracy or brigandage, and by war for the conquest of slaves, and should be maintained by slave works" (quotation in Novak, 1993, p. 105). In the course of history, the colonial powers acquired a great deal of wealth, usually with no regard for legal and ethical concerns, which, by and large, amounted to a redistribution rather than a creation of wealth. In the capitalistic system, the "acquisitive spirit," "the accumulation of capital," and the "acquisition of companies" do not necessarily entail the creation of wealth, properly speaking. It is, therefore, crucial to investigate precisely what this concept of "creation" means.

To create is to make something new and better. Take the example of Medtronic Inc., which is proud to be "the world's leading medical technology company, providing lifelong solutions to chronic disease" (http://www.medtronic.com). In its over 50 -year history, it has developed a wide range of medical devices, from heart pacemakers to devices to alleviate neurological and spinal disorders and to manage diabetes, and it continues to be in the forefront of the industry (see Financial Times, "Medtronic shows off future of healthcare," February 8,2002$)$. Inspired to serve the customers, its innovative spirit has revolutionized not only its products and services but also its production processes, organization, culture, and identity, while yielding continuous financial success. As this company illustrates, while wealth creation has a lot to do with technological innovation, it is more than that, since the innovation is made feasible and successful in economic and financial terms. Aiming at material improvement for the benefit of human lives, wealth creation includes both a material and a spiritual side, and goes beyond the mere acquisition and accumulation of wealth. It is a qualitative transformation of wealth.

On a national scale, the meaning of wealth creation can be easily understood against the backdrop of the debacle of a war. In the aftermath of the Second World War, Germany and Japan had to create, to a large extent, new economies; China as well, after the traumatic civil war of the Cultural Revolution (1966-1976), engaged in a transformation process from a centrally planned to a market-oriented economy. In those situations, creating wealth is a national objective that mobilizes a great many forces for a new and better future. In general, the state and companies operate on a broad consensus regarding the need for the creation of both public and pri vate wealth. Without a doubt, the material side of these endeavors is essential, but the spiritual (or ideological) side is indispensable as well. As a good example for both the material and spiritual com- 
mitment of companies to participate in public wealth creation, we may recall Konosuke Matsushita's determination in 1954 to continue, despite serious financial difficulties, the joint venture with Philips. "I definitely do not think that the tie-up has been a failure.... I did not choose to form a technical tie-up with Philips to stimulate the growth of Matsushita Electric. I did not do it to gain personal publicity. I did it in order to bring the underdeveloped electronics industry in Japan up to world standards more quickly" (Yamaguchi, 1997, p. 6). ${ }^{3}$

In further exploring the notion of wealth, we may question its purpose and use, first in economic terms and then in noneconomic terms as well. Besides the fact that wealth creation can have intrinsic value (for instance, the hard and diligent work and great enjoyment of producing life-saving medical equipment), wealth has instrumental value, being usable for consumption or investment. If consumption is the sole purpose, then the road to poverty is predetermined. For an historic example, we may recall the decline of Spain in the seventeenth century. As Landes writes (1999, p. 175), "Spain ... became (or stayed) poor because it had too much money. The nations that did the work learned and kept good habits, while seeking new ways to do the job faster and better. The Spanish, on the other hand, indulged their penchant for status, leisure, and enjoyment, what Carlo Cipolla calls 'the prevalent hidalgo mentality'." Furthermore, Landes offers a moral (relevant to the United States of today): "Easy money is bad for you. It represents short-run gain that will be paid for in immediate distortions and later regrets." (p. 173)

Investment is necessary for both wealth maintenance and growth. Of course, if the investment rate is very high, then the present generation may carry an undue burden of reduced consumption for the benefit of future generations. However, today's consumer society tends to move in the opposite direction with a high preference for consumption to the detriment of investment. This trend becomes particularly clear when we take into serious account not only "the nature of wealth" but also "the wealth of nature.", One can reasonably argue that humankind at present is over-exploiting nature, the costs of which future generations will have to pay. It is therefore imperative to include the concept of sustainability in our notions of consumption, investment, and wealth. Wealth creation must be "sustainable," fulfilling the demand "to meet the needs of the present without compromising the ability of future generations to meet their own needs" (as defined by the World Commission on Environment and Development, see WCED, 1987, p. 8).

While this definition clearly presupposes a wide, intergenerational time horizon, it does not specify "the needs" of the present generation and "the ability" of future generations to meet their own needs. I, therefore, suggest adopting Amartya Sen's "capability approach," masterfully crafted in Development as Freedom (1999), to substantiate the concepts of needs and capabilities in this definition of sustainability. Development is defined as "a process of expanding the real freedoms that people enjoy" (Sen, 1999, p. 3). Although Sen does not directly refer to the WCED definition, from the outset he mentions "worsening threats to our environment and to the sustainability of our economic and social lives." He argues that

individual agency is, ultimately, central to addressing these deprivations. On the other hand, the freedom of agency that we individually have is inescapably qualified and constrained by the social, political and economic opportunities that are available to us ... It is important to give simultaneous recognition to the centrality of individual freedom and to the force of social influence on the extent and reach of individual freedom. In order to counter the problems that we face, we have to see individual freedom as a social commitment. (Sen, 1999, pp. xi-xii)

In addition, it is easily ignored that wealth creation involves a distributive dimension, permeating all of its stages from the preconditions to the generation process, the outcome, and the use for and allocation within consumption and investment. In fact, the productive and the distributive dimensions of wealth creation are intrinsically interrelated. However, the separation between "producing the pie" and "sharing the pie" has marked for too long the ideological struggle between "the right" and "the left," despite its flawed economic underpinning. The time has now come to correct this misleading separation and to take the interrelations between the two dimensions (again) into account.

Having clarified different aspects of the concept of wealth creation, we now turn to the question of 
motivation. What motivates people, companies, and countries to engage in wealth creation? Common answers in the economic and sociological literature are self-interest, greed, the will to survive, the desire for power aggrandizement, the enjoyment of riches, and the glory, honor, and well-being of nations. However, these motivations, taken individually or in mixed combinations, are rarely related specifically to the creation of wealth, but instead drive economic activities in general and, most often, incite merely the acquisition and possession of wealth. When economic activities clearly focus on wealth creation, other motivations such as the entrepreneurial spirit, the desire to serve others, and the joie de trouver [or the 'joy of finding' that, in Landes's judgment (1999, p. 58), was the distinctive motivation in medieval Europe as compared to Islamic countries and China] become more important. At the same time, the purpose of business and consequently its role in society gets elevated. Business is no longer just about making money and acquiring wealth, relegated to the role of the ugly, yet indispensable servant that provides others with the material means to pursue higher, i.e., spiritual ends. Accordingly, it does not deserve a low reputation that is, unfortunately, even reinforced by those who stress the purely material and instrumental view. Rather, it is a creative and thus noble activity including both material and spiritual aspects, driven by a mix of motivations that are self- and other-regarding.

We may ask why, in history, wealth creation has often been ignored, disregarded or even treated with contempt. It seems to me that these attitudes depend on the valuation of the material world and the "bodiliness" of the human person as well as on the notion of creation. If the material world is considered inferior or even evil and if hostility towards the human body prevails, then wealth cannot but share these qualities and is likely to be denigrated. Operating under those assumptions, it becomes nonsensical to produce such wealth, were it not for another, really valuable purpose. Moreover, without proper understanding, the creation of wealth cannot be really appreciated for its capacity to serve as a purpose of economic activity that matters more than the possession and acquisition of wealth. In sum, the determined affirmation that wealth creation is both good and necessary constitutes an essential prerequisite for thriving business in the long run. This necessarily includes, as mentioned above, a distributive dimension that permeates the entire creation process. It deeply affects the motivation for wealth creation as this motivation, in turn, strongly impacts wealth distribution.

What has been developed in the previous conceptual clarifications of wealth creation can be substantiated with Benjamin Friedman's study on The Moral Consequences of Economic Growth (2005). A prominent economist, he provides the facts and the analyses of how economic growth or stagnation may interact with the moral character of society and its social and political development over time. Carefully researching the histories of the United States, Britain, France, and Germany as well as the economics and politics in the developing world, he develops a deep understanding of "economic growth," similar to our notion of wealth creation. Economic growth is the production of a combination of private and public goods by both market forces and public policy. It should be broadly based and sustainable, thus involving necessarily a distributional and an environmental dimension. Economic growth has not only negative side-effects but also bears moral benefits in terms of openness of opportunities, tolerance of diversity, economic and social mobility, commitment to fairness, and dedication to democracy. In turn, the moral quality of society affects economic activity and policy. Consequently, Friedman conceives economic growth in both material and moral terms and rejects opposing material versus moral considerations as a deeply flawed and false choice.

\section{Challenges for business ethics}

After exploring the meaning of wealth creation, we now try to relate it to business ethics. However, by doing so, aren't we sending owls to Athens? Isn't this relationship so obvious that any thought would be superfluous? $?^{5}$ After all, business is about producing wealth, and ethics has to make sure that this is done properly. Nevertheless, I would like to argue that we need to pay serious attention to this relationship because, without this focus, business ethics becomes a superficial undertaking, evading the struggle with arguably the central issue of economic activity while expanding its reach far beyond what it can and should deliver. 
In my view, a thorough understanding of wealth creation enables us to sharpen our economic critique of fashionable and short-sighted management recipes and to bring the power of ethics to bear where it matters most. From the conceptual analysis in the previous section, we can draw a number of lessons for a sound, comprehensive, and differentiated understanding of business ethics. Equating business with just making money is not only questionable from the ethical perspective, one that asks for the ethical quality of both its means and its ends, but also from the economic perspective. Without adequate economic underpinning, making a lot of money can entail the destruction of much wealth, as the recent debacles of Enron and such others have demonstrated. ${ }^{6}$

It is relatively easy, though necessary as well, to criticize scandalous business behavior. However, from the perspective of wealth creation, examples of an innovative spirit and best practices of "making things new and better" are more inspiring and should play a more prominent role in business ethics research and teaching. They would also highlight the fact that wealth creation forces the economic actor to look beyond the short term and definitively adopt a long-term perspective as well, in which "sustainability" is the key. As examples, we may mention Medtronic Inc. (see above), Rohner Textil AG (www.climatex.com), and the Grameen Bank (www.grameen-info.org; the latter two companies being featured in Enderle, 2004).

When exploring the concept of the wealth of nations, we concluded that it should encompass both private and public wealth. As we know from economic theory, properly functioning markets are powerful instruments to create private wealth, but they fail in creating public wealth. This involves farreaching implications for business ethics. Business ethics should not be limited to the creation of private wealth and reduced to corporate ethics, that is, the ethics of business organizations, because the economy is bigger than the realm of markets and companies. Rather, business ethics should include the ethics of the economic system (and therefore go beyond "market morality"). It is only in this context that the creation of wealth with its productive and distributive dimension and, we may add, the re-distribution of wealth, can be treated in a proper and comprehensive manner.
With regard to globalization, wealth creation provides a focus for business ethics, the importance of which cannot be overestimated. As long as globalization is the acquisition of wealth, most often by the rich from the poor, it does not create, but only reshuffles and redistributes wealth, although accumulated wealth may masquerade as created wealth. The creation of sustainable wealth is a highly complex and demanding process and cannot be achieved without paying serious attention to its distributional preconditions and consequences. Moreover, if it is true at the national level that the creation of private wealth necessitates a certain amount of public wealth, then the same is likely to hold at the international and global levels. Given the difficulties in creating public wealth at the local and national levels, one can easily imagine the almost insurmountable problems to do so at the global level.

These difficulties in creating wealth call for a thorough examination of motivations. They should be strong and effective, providing the driving force necessary not simply for acquiring and possessing wealth but, more importantly, for creating wealth. Furthermore, they should aim not only at private, but also at public wealth at all levels, from the local to the global. Recalling the array of motivations indicated above, I suggest considering a mix of motivations that are self- as well as other-regarding. Certainly, self-interest and the honor of the country remain powerful driving forces and, if properly understood, are ethically legitimate. However, if they are purported as the sole important motivations (for economic activity), then they are questionable on empirical grounds and can involve grave inconsistencies (for instance, the self-interest of the manager may conflict with the self-interest of his/ her company, or the honor of the country may require the sacrifice of the individual's interests). For the very creation of wealth, as mentioned above, other motivations such as the entrepreneurial spirit, service to others, and the joy of finding (that might be combined with the will to make a decent living for oneself and one's family) assume more importance and are indispensable to producing public wealth. Generally speaking, the enormous challenges of creating wealth require a shift in motivations that shape the cultures of companies, countries, and the world. However, such a shift 
cannot take place unless it is internalized and advanced by individuals.

The motivation for wealth creation can be further strengthened to the extent that the production of economic wealth is intrinsically coupled with the production of non-economic, e.g., social and environmental, wealth, thus designed "to hit two birds with one stone." No doubt, to achieve this is an even bigger challenge to the entrepreneurial spirit, but the gain is bigger as well. At the organizational level, companies can employ strategies that simultaneously fulfill both economic and also social and environmental responsibilities so that the different dimensions of corporate activities reinforce rather than weaken each other.I offer a few examples: Activities such as feeding hungry workers in poor areas will improve their productivity. Empowerment of workers on the shop floor will have a similar wealth-enhancing effect. Extending a plantation's water system into the local squatter community or investing in a hospital will improve worker health and motivation with a resulting productivity and positive cash-flow impact. In the environmental realm, programs to reduce energy consumption can enhance economic wealth. In other words, economic growth not only generates the means for social and environmental progress, but also social and environmental advances can enhance the economic performance of companies. As Benjamin Friedman points out for the societal level, there is also interaction between economic, social, and environmental activities at the corporate level. In order to account for this interrelationship, we may speak of a "balanced concept of the firm," which, in my view, is one of the top challenges for corporate ethics in the twenty-first century (see Enderle, 2002a; Enderle and Tavis, 1998).

Having said this, we should not forget that wealth creation at the national as well as the international level is a combined production of private and public wealth. This means that companies cannot generate wealth without benefiting from public wealth, and public wealth cannot be created without profiting from companies. In addition, this implies that companies should not be held responsible for nearly everything as many champions of CSR seem to demand; however, they do bear responsibility (shared with other social actors) for creating public wealth, which those deny who claim that profit maximization be the sole responsibility of business.

\section{Conclusion}

In this essay, we have tried to show the need for taking a fresh look at the creation of wealth. From a global perspective it is crucially important to understand why some countries are so rich and some are so poor. From a business perspective and in the wake of the financial and economic crisis, it seems necessary to better calibrate the purpose of the corporation. We suggest adopting a multifaceted concept of wealth and a genuine understanding of its creation. Wealth is more than financial capital by including physical, human, and social capital. Wealth is not only private wealth but also encompasses public wealth, both influencing each other in multiple ways. Because the process of wealth production inescapably involves a distributive pattern, wealth creation and wealth distribution, strictly speaking, cannot be separated (often, "wealth distribution" actually means wealth re-distribution). Wealth is not merely material, but also has a spiritual side, which ennobles its creation to a truly human activity. By placing wealth creation in the time horizon of sustainability enriched by Sen's capability approach, one overcomes an exclusively short-term view and integrates an intergenerational fairness perspective. The emphasis, on creating as distinct from possessing and acquiring, highlights the need for innovation in both private and public wealth creation and requires "mixed" motivations (that is self- and otherregarding) to overcome the exclusive and thus insufficient motivations of either self-interest or collective interests.

Such a rich concept of wealth creation involves far-reaching consequences for business ethics. It brings the power of ethics to bear where it matters most: the proper understanding of wealth, its creation, and the motivations thereof. The purpose of business becomes a noble and sustainable goal that diligently serves customers, attracts talented and committed employees, provides decent returns to investors, and protects the environment. Because the wealth of a nation (and of similar entities from the local to the global level) results from the combination of private and public wealth, business ethics should include the ethics of economic systems and deal with the proper roles the various social actors should play in this systemic context. With regard to globalization, business ethics should not content itself with the 
acquisition and/or redistribution of wealth; rather it should focus on genuine wealth creation, particularly among the losers of globalization.

\section{Notes}

1 On a personal note, I may add my exposure to and my interest in the question of wealth creation, having taught and done research in China for many years.

"To be rich is glorious," a famous saying attributed to Deng Xiaoping in the mid 1980s (see note 2) marked a radical change of attitude toward wealth and prosperity, one that came to constitute a core value of the moral foundation for China's economic reform and open-door policy. It has been embraced by millions and millions of Chinese and proved, overall, to be quite successful. I personally have been fortunate, since 1994, to observe and study the remarkable economic development in China and, particularly, in Shanghai, to seek possible lessons applicable to other parts of the globe and to reconsider my own views with regard to poverty and wealth and business responsibility.

These Chinese challenges are in stark contrast to what I had experienced before my involvement with China and in other regions of the world. Highly motivated by an eye-opening trip to India in summer 1970, I wanted to complement my education in theology with studies in economics, especially on poverty and income inequality. My focus was clearly on the poor, not the rich. How could the rich be "glorious" when, as Jesus said, "it is easier for a camel to go through the eye of a needle than for someone who is rich to enter the kingdom of God" (Luke 18: 25)? Although living in Europe, I was strongly influenced by the Latin American theology of liberation, the preferential option for the poor, and the debate on the pastoral letter Economic Justice for All of the U.S. Catholic bishops (Enderle, 2002b). To fight against poverty made sense. Jesus' saying that "you always have the poor with you" never meant to me to accept the fact of poverty in resignation and to give up the hope to essentially eradicate poverty. Thus, I wrote my "habilitation" (Enderle, 1987) in business ethics on economic and ethical aspects of poverty in Switzerland and, by doing so, discovered how poverty research can open up a wide range of perspectives that are also of great relevance to business and economic ethics in general (see Enderle, 1991). However, at that time I didn't realize the importance of the creation of wealth. In the 1990s; I was increasingly exposed to two very different types of continental experiences. I couldn't help comparing them on a continuous basis, although such comparisons are certainly incomplete and somewhat biased and unfair. My connections to and activities in Latin America, and particularly my involvement in the long preparation of the World Congress of Business, Economics, and Ethics in São Paulo (2000), helped me to understand more deeply the ethical challenges of business ethics on that continent and the presence of Catholicism in its multiple forms (see Enderle, 2003). My trips to East Asian countries and my studies of some of their core ethical issues opened my Western eyes to a very new and highly complex reality with which I still have difficulty coming to grips (see Enderle, 1995; Lu and Enderle, 2006).

In juxtaposing and comparing those countries' experiences, I'm beginning to understand how important a proper concept of and a determined focus on wealth creation are precisely for addressing the issues of poverty and inequality between income and wealth. Furthermore, these vital problems cannot be dealt with in a purely technical and value-free manner. Culture and religion obviously matter, and their impact, for better or worse, needs to be investigated and evaluated.

2 Remark about the saying "to be rich is glorious": This saying (zhi fù guāng róng), actually, was neither directly uttered nor denied by Deng Xiaoping. A journalist asked the leader in an interview on September 2, 1986: "How would Mao Zedong see the current situation?" and proposed the answer that remained uncontested by Deng Xiaoping: "In such a way as the current leaders maintain that to be rich is glorious...." (Deng Xiaoping's Selected Works in Chinese, Vol. 3, People's Publishing House, Beijing, 1993, p. 174). I acknowledge my gratitude to Xiaohe Lu for this information.

3 One might ask, "Whether this innovative spirit leading to wealth creation is one or even the essential feature of capitalism?" Different scholars offer a variety of answers. David Landes argues that it was already in the Europe of the Middle Ages when the division of labor and widening of the market encouraged technological innovation (Landes, 1999, p. 45). For the peculiarly European cultivation of invention, as distinct from the Chinese attitude, he stresses the importance of the market. "Enterprise was free in Europe. Innovation worked and paid, and rulers and vested interests were limited in their ability to prevent or discourage innovation. Success bred imitation and emulation; also a sense of power that would in the long run raise men almost to the level of gods" (p. 59).

For Michael Novak, the innovative spirit becomes the hallmark of capitalism. Criticizing Max Weber who holds "economic rationality" to be the essence of capitalism and drawing on Hayek, Schumpeter, Kirzner and others, Novak states: "The heart of capitalism ... lies in discovery, innovation, and invention. Its fundamental 
activity is insight into what needs to be done to provide a new good or service. The distinctive materials of capitalism are not numbers already assembled for calculation by the logic of the past. On the contrary, its distinctive materials are new possibilities glimpsed by surprise through enterprising imagination" (Novak, 1993, p. 10).

4 An interesting attempt to take nature into account has been made in the report to the Club of Rome by Van Dieren (1995).

5 One might wonder whether this is the reason why an entry on "wealth" (and on "poverty" as well) is missing in the Encyclopedic Dictionary of Business Ethics (Werhane and Freeman 1997, 2005).

6 With the benefit of hindsight, we wouldn't qualify Enron as a company that created enormous wealth in the late 1990s despite its spectacular published financial results: its operating results, for instance, increased from $\$ 515$ million in 1997 to $\$ 698$ million in 1998 , to $\$ 957$ million in 1999 , and to $\$ 1.266$ billion in 2000 . The bankruptcy filing lists $\$ 31.2$ billion of debt, later revised to $\$ 40$ billion, and the asset values estimated at $\$ 62$ billion in the Chapter 11 filing were later revised to $\$ 38$ billion (Tonge et al., 2003, p. 5).

\section{Acknowledgment}

I would like to thank the Editorial Managers, Geoff Moore and Christoph Stückelberger, for organizing this Special Issue, and the two anonymous reviewers for their helpful comments.

\section{References}

Collins, J. C: 2001, Good to Great. Why Some Companies Make the Leap - and Others Don't (HarperBusiness, New York).

Collins, J. C. and J. I. Porras: 1994, Built to Last. Successful Habits of Visionary Companies (HarperBusiness, New York).

Enderle, G.: 1987, Sicherung des Existenzminimums im nationalen und internationalen Kontext. Eine wirtschaftsethische Studie [Securing the Minimal Standard of Living in the National and International Context: A Business Ethics Perspective] (Haupt, Bern).

Enderle, G.: 1991, 'La pauvreté, paradigme de l'éthique économique', in R. Rémond (ed.), Démocratie et pauvreté. Du quatrième ordre au quart monde (Editions Quart Monde/Albin Michel, Paris), pp. 453-469. [In German: 'Das Armutsproblem als Paradigma der
Wirtschaftsethik', in P. Eicher (ed.): 1989, Neue Summe Theologie, Vol. 2 (Herder, Freiburg), pp. 340-373].

Enderle, G.: 1995, 'An Outsider's View of the East Asian Miracle: Lessons and Questions', in S. Stewart and G. Donleavy (eds.), Whose Business Values? Some Asian and Cross-Cultural Perspectives (Hong Kong University Press, Hong Kong), pp. 87-120.

Enderle, G.: 2000, 'Whose Ethos for Public Goods in a Global Economy? An Exploration in International Business Ethics', Business Ethics Quarterly 10(1), 131-144.

Enderle, G.: 2002a, 'Algunos vinculos entre la ética corporativa y los estudios de desarrollo,' in B. Kliksberg (ed.), Ética y Desarrollo. La Relación Marginada (El Ateneo: Buenos Aires), pp. 345-372 [English title: 'Corporate Ethics at the Beginning of the 21st Century'].

Enderle, G.: 2002b, 'The Option for the Poor and Business Ethics', paper presented at the conference The Option for the Poor in Christian Theology on November 10-13, 2002, at the University of Notre Dame. Manuscript available from the author.

Enderle, G. (ed.): 2003, 'Special Section: Religious Resources for Business Ethics in Latin America', Latin American Business Review 4(4), 87-134.

Enderle, G.: 2004, 'Global Competition and Corporate Responsibilities of Small and Medium-Sized Enterprises', Business Ethics: A European Review 13(1), 51-63.

Enderle, G. and L. A. Tavis: 1998, 'A Balanced Concept of the Firm and the Measurement of Its Long-Term Planning and Performance', Journal of Business Ethics 17(11), 1121-1144.

Friedman, B. M.: 2005, The Moral Consequences of Economic Growth (Vintage Books, New York).

Heilbroner, R. L.: 1987, 'Wealth', in J. Eatwell, M. Milgate and P. Newman (eds.), The New Palgrave: $A$ Dictionary of Economics, Vol. 4 (Macmillan, London), pp. 880-883.

Kaul, I., I. Grunberg and M. A. Stern (eds.): 1999, Global Public Goods. International Cooperation in the 21st Century (United Nations Development Programme, Oxford University Press, New York).

Landes, D. S.: 1999, The Wealth and Poverty of Nations: Why Some are so Rich and Some are so Poor (New York, Norton).

Lu, X. and G. Enderle (eds.): 2006, Developing Business Ethics in China (Palgrave Macmillan, New York). (In Chinese published by Shanghai Academy of Social Sciences Press, 2003.).

Myrdal, G.: 1968, Asian Drama: An Inquiry Into the Poverty of Nations (Pantheon, New York).

Novak, M.: 1993, The Catholic Ethic and the Spirit of Capitalism (Free Press, New York). 
Sen, A.: 1999, Development as Freedom (Knopf, New York).

Smith, A.: 1776, An Inquiry Into the Nature and Causes of the Wealth of Nations, edited by R. H. Campbell R. H., Skinner, A. S. and W. B. Todd, 1976, (Clarendon Press, Oxford).

The Economist: 2005, The Good Company, Special Survey, January 22.

Tonge, A., L. Greer and A. Lawton: 2003, 'The Enron Story: You can Fool Some of the People Some of the Time...', Business Ethics: A European Review 12(1), 4-22.

Van Dieren, W. (ed.): 1995, Taking Nature Into Account: Toward a Sustainable National Income (Springer, New York).

Werhane, P. H. and R. E. Freeman (eds.): 1997, The Blackwell Encyclopedic Dictionary of Business Ethics (Blackwell, Malden, MA).

Werhane, P. H. and R. E. Freeman (eds.): 2005, The Blackwell Encyclopedia of Management, Vol. II: Business Ethics, Second edition (Blackwell, Malden, MA).
World Bank: 1993, The East Asian Miracle: Economic Growth and Public Policy (Oxford University Press, New York).

World Bank: 2007, WDI Online [electronic resource]. World Development Indicators (World Bank, Washington DC).

World Commission on Environment, Development (WCED): 1987, Our Common Future (Oxford University Press, New York)

Yamaguchi, T.: 1997, 'The Secret of Matsushita's Success. Five Principles of Rational Humanistic Management', Presentation at the Beijing International Conference on Business Ethics.

Mendoza College of Business, University of Notre Dame, Notre Dame, IN 46556, U.S.A. E-mail:genderle@nd.edu 